\title{
Four Basic Dimensions to Evaluate the Quality of Ideological and Political Education Theory Research
}

\author{
Jingkun $\mathrm{Lu}^{1, \text { a }}$ \\ ${ }^{1}$ School of Political Science in Chongqing Normal University, Chongqing, 401331 \\ a email
}

Keywords: Ideological and political education, research study, research quality, evaluation dimension

\begin{abstract}
For 30 years since the birth of ideological and political education, theoretical research results continues to spring up. At present, the main task of promoting the deep development of ideological and political education is to make a scientific evaluation on the theory of ideological and political education. Scientific assessment of the quality of ideological and political education theory needs to adhere to the four basic dimensions: position dimension, practical dimension, specification dimension and the innovation dimension.
\end{abstract}

\section{Introduction}

The birth of the ideological and political education makes the theoretical study of the ideological and political education walks into a new stage relying on the propulsion of specialized profession, specialized subject and specialized team. For about 30 years since the birth of ideological and political education theoretical research results have been coming out with great achievements. But at the same time we should also see clearly that the ideological and political education theory research still exists problems and the insufficiency in different degrees, such as little high-quality theories, poor-quality practical researches and weak social influence of the theory achievement. At present, the scientific evaluation of the ideological and political education theory research should become an important driving force to the sustainable development of ideological and political education. To evaluate the quality of ideological and political education theory research should grasp the following four basic dimensions.

\section{The Position Dimension}

Position dimension refers to whether to insist on Marxism to guide the theoretical study of the ideological and political education as the first dimension to evaluate the quality of the ideological and political education theory research. Here the insistence is not to dogmatically adhere to individual judgment and specific conclusions that Marx and Engels as well as their successors made under specific historical conditions, but to insist on the public position, dialectical materialism and historical materialism viewpoints of Marxism, and the dialectical materialism, seeking truth from facts, mass line way of thinking and working method, and apply to theoretical research and practice of ideological and political education research.

To set the position dimension as the first dimension to evaluate the quality of the ideological and political education theory research is decided by the science of Marxism itself and also is decided by the subject attribute of ideological and political education. Marxism knows the world of the true nature of the world, reveals the scientific theoretical system of the objective world especially the essence and the regulation of the human society. The scientific nature of Marxism has been tested and verified by repeatedly practice. As Lenin pointed out that if you want to ask why Marx's theory can realize the heart of the most revolutionary class of ten million people, then you only can get one answer. This is because Marx relies on the solid foundation of all the knowledge that human gains under capitalism; he studies the development regulation of human society. Marx realizes the development of the capitalism inevitably leads to communism, which he concludes completely according to the most exact, careful and profound 
research of the capitalist society with the aid of fully grasp all previous scientific knowledge[2]. It is because Marxism is scientific, the proletariat makes Marxism as the sprigtail weapons when seeking its liberation; the Chinese Communist Party makes Marxism as the fundamental guiding ideology of our party; the ideological and political education makes Marxism as its guiding ideology, theoretical basis and basic education content. At the same time, as "in the divided society with class contradictions, there never can be a class or ideology above classes at any time" [3]. And "the ideas of the ruling class are the dominant ideology in every era" [4]. In order to make the ideas of the ruling class really become the dominant ideology, people create a special practice activity, the ideological and political education. It should be pointed out that the establishment of the concept of "ideological and political education" is produced after the birth of Marxism, but as a special kind of practical activity, it is an objective existence of practice since human society enters the class society and country. It is called differently in different time and different country. The ideological and political education of the Chinese communist party is created when the communist party of China leading people in practice to master the practice of members in the community using socialist ideology and socialism thoughts. For better mastering society members, we must study the formation and development rule of ideology and moral character and the rule of the ideological and political education, which gives rise to the birth of the ideological and political education. The subject studies how to use the theory and method of Marxism to help people set up the correct world outlook, the outlook on life and the values, which asks people to set Marxism as a guide to carry out its theoretical research and discipline construction. The 30 years development history of Ideological and political education proves that whether to carry out the ideological and political education theory research or take out concrete practice, all must be always insist on Marxism, or the study of the theory of the ideological and political education will lost direction because there is no correct guiding ideology, theoretical basis and ideological soul. And the actual operation of ideological and political education will be a failure because there is no scientific world outlook and methodology guidance.

In the real research of ideological and political education theory, every deviation or departure from the guidance of Marxism is the appearance of not insisting on the position dimension in the research of ideological and political education theory, such as take neutral attitude in the research , try to water down or abandon the ideology of ideological and political education, or in the name of adhere to Marxism, but "insist on other theories", "Abstract affirmation, concrete negation", "modify and understood arbitrarily" and so on. Because of a deviation or departure from the guidance of Marxism, such research results only have inferior quality, have no value, or even a negative value of research, even if they have innovative ideas, arguments, and language.

\section{Practice Dimension}

One of the important dimensions to evaluate the quality of the ideological and political education theory research is practical dimension, namely changing from whether the ideological and political education theory research achievements are adopted by relevant departments into government policies or measures of school or the education of ideological and political educators concept and behavior, and thus to promote the development of the ideological and political education practice at a higher level as the important dimension of the evaluation of ideological and political education theory .

To put the practice dimension as an important dimension of evaluating the research quality of ideological and political education is determined by the inner purpose of theoretical research, is also determined by the requirement of improving the effectiveness of the ideological and political education. People are engaged in theoretical research for the purpose of creating the object world, changing the inorganic world, making the outside world connects with people in a better way, making people's practice to realize the regularity and purpose of unification. An important purpose of people engaged in theory research is to reveal things with universality and regularity in certain conditions formed in the practical activities, and express it with certain words to guide the practice, which enables objective material world to create connection with people as instructed, thus to create more "things" to satisfy the needs for 
survival and development of people. Marx once pointed out: "It is not a theoretical problem whether people's thought is objective, but a practical problem. People should prove the truthfulness of his thinking in practice, which is the reality and strength of their own thinking, the sidedness of his thinking."[5] The results of theory research only returns to the practice can be tested, amended, supplemented and perfected; results of theoretical research only returns to the practice can not only reflect the world but also create the world. Because "the achieve degree of theory in a country always depends on the degree that the theory can meet the needs of the country", [6] therefore, theoretical study if just "say to itself", lacks "continuous saying" "go on saying" of practice, the practical research has lost its value. Thus whether the theoretical research results can be converted into action concept of the practice and reflect in their actions is related to whether the theory can change from "critical weapon" into "weapon for criticism", decides the size and the presence of the theoretical value. What needs to stress is that this practice subject includes "the people in reality and can be observed through experience, in the process of development under certain conditions" [7], but also these groups and organization.

For 30 years since the birth of ideological and political education discipline, a number of research results have came out, but the quality of the research is not equal to the number of researches. In nowadays era, world multi-polarization and economic globalization are developing further and science and technology has rapid progress, all kinds of culture blend exchange more frequently. New change and new situation have brought unprecedented new challenges to ideological and political education and proposed more difficult new tasks. The theoretical study of the ideological and political education should face the real ideological and political education practice under the new situation and new change, tries to use abstract in thinking to "discovery" things with regularity and universality through the complicated phenomenon of "combined ideological and political education", and based on this, to put forward practical and workable measures to strengthen and improve ideological and political education of the party, enhance the effectiveness of ideological and political education, so as to effectively guide the development of the ideological and political education practice and promote the development of ideological and political education at a higher level. Marx and Engels criticized the young philosophers of Hegel in German Ideology because "no one thought of putting forward the connection between the German philosophy and the realistic problems, about the connection problems of their criticism and their physical environment problems" [8], as a result, although these philosophers spoke of the so-called "words shocked the world", in Marx and Engels's view, they were the largest "conservatives"[9]. In the practical theoretical study of ideological and political education, those theorists lack the courage to face the reality, have little attention, analysis, research and strive to resolve a series of new situations and problems in the real ideological and political education practice activity. Although they spare no efforts to gain the achievements in the study of literature research with eyeful words of "shock the world", due to the alienation of the real ideological and political education activities, they can not provide adequate explanation to the complex variety of ideological and political education activities, not even guide the effective development of ideological and political education activities. Therefore, those researchers are also the biggest "conservative”, the research achievements have inferior quality.

\section{Standard Dimension}

Standard dimension is an important dimension to evaluate the quality of the ideological and political education theory research, which is embodied in theoretical examination on the ideological and political education academic creation activities. To evaluate the quality of ideological and political education theory research in the view of standard dimension should emphasis on whether theoretical research adhere to the academic norms, whether it spares no efforts to solve theoretical and practical issues in the field of ideological and political education discipline.

The academic norms are the basis of academic activities, and following the academic norms is the indispensable condition for high quality of theory research results. Academic norms in ideological and political education theory research are embodied in "discourse, topic selection, study, methods, argument 
specification, style, attribution, citation and ethics norms and etc”.[10] The ideological and political education theory research only follows the academic norms is scientific and effective study and to produce high quality of theory research results. The important standard of assessing the quality of ideological and political education theory research is whether it follows the academic norms. In addition, whether it sticks to the subject position, disciplinary boundaries to carry out theoretical research should also be an important measure to evaluate the quality of the ideological and political education theory research. As the practice of the ideological and political education is a complex activity, the comprehensive and complexity of its research object and solving the problem needs to analyze through widely absorbing relevant achievements and resolve through interdisciplinary cooperation. The study team researchers of ideological and political education came from different positions such as soldiers, the practice enterprise workers, universities, research institutions, their subject background, knowledge structure, professional quality, ideological and political education discipline are all various, which makes the interdisciplinary research be burgeoning since the establishment of the ideological and political education discipline. It is also the result of absorbing and reference of other related disciplines, methods; the ideological and political education theory research has made such great abundant research achievements in short 30 years to a more mature theoretical height. But at the same time we should also see clearly that due to the blind expansion of domain in the interdisciplinary research, simple copy and theory attachment when referring theory or method from other disciplines, subject boundary is blurring. It shows that topics are more and more complex, the volume is bigger and bigger and the system is numerous and some other aspects. We can list the contents of the doctorate dissertation and the relevant ideological and political education to express slightly. In 1997, the ideological and political education subject began to enroll graduate students. Some scholars found after overall analysis of the thesis within ten years from 2000 to 2009 there were 96 doctoral dissertations having no direct relation with the ideological and political education discipline, which accounts for $31.4 \%$ in the passed $306 \mathrm{Ph} . \mathrm{D}$. Thesis. These dissertations overlap with Marxist philosophy, scientific socialism, the party construction of party history, ethics, political science and other disciplines, improperly contain quite a broad "extension”. Dissertation without indicating the name of profession and research direction simply distinguish exactly which subject of Ph.D. Thesis".[11] In the theoretical study of the ideological and political education discipline, the existence of subject unknown, large package volume, miscellaneous but not professional not only have a bad effect on the "legitimacy" and "rationality" of the subject to a certain extent, but also "may contribute to prosperity in the form of the ideological and political education research, and is likely to lead the study losing itself facing the prosperity, which is not conducive to the deepening and development of the real ideological and political education theory research, is not conducive to forceful response on a series of important problems in the practice of ideological and political education theory research on ideological and political education”. [12] As a result, clear disciplinary boundaries and really focus on theoretical study of ideological and political education discipline is an important basis to evaluate the quality of the ideological and political education theory research.

\section{Innovation Dimension}

Evaluating the quality of ideological and political education theory research needs to take innovation as an important dimension. It means whether it takes the basic principle, basic idea and basic method of Marxism as the important basis to evaluate the quality of the ideological and political education theory research, gives theoretical and abstractive summary to new things, new situation, new problem and new contradiction in the new situation of ideological and political education, so as to promote the development of the ideological and political education practice at a higher level.

At present, with the rapid development of science and technology, the transmission methods and the changeful social thoughts, the external environment of ideological and political education, the domestic condition and work objects have changed a lot. The international environment, the world is in the period of great development, change and adjustment. Ideas blend between cultural exchanges more frequently, 
the international media situation that "western strong, our country weak" has not yet to be fundamentally reversed; the domestic environment, under the condition of rapid development and advancement of the reform and information communication technology by leaps and bounds, various social contradictions overlap with each other and appear in collective, people thoughts change more apparently, formation and transmission channel of public opinion are more complicated; the objects, highly homogenized social group structure before the reform has changed and develops in the direction of diversification. The original "two class, one stratum (that is the worker, farmer class and the intellectual stratum)" social structure has differentiation, the new social strata continuous to spring up, including entrepreneurship and technical personnel in the private scientific and technological enterprises, the management and technical personnel employed by foreign companies, self-employed and private business owners, intermediary organization practitioners, free profession personnel etc. At the same time, emerging groups also come out because of the social stratum differentiation and social class flow such as the "the second rich generation" and "the second poor generation", the "ant tribe", such as the "the second migrant workers generation". The change of scope, object and environment brings unprecedented challenges to the new time ideological and political education. How to guide with Marxism according to the change of ideological and political education environment to create a new theoretical result to guide the practice is the task of the research. A match whether can be guided by the Marxism according to the changes in the ideological and political education environment to create a new theoretical result to guide the practice has become an important basis to evaluate the quality of the ideological and political education theory research.

The theoretical research of ideological and political education is not for the innovation but to respond and solve major theoretical and practical problems put forward in the practice of ideological and political education, in order to better guide practice and theory innovation. The practice far away from the ideological and political education takes theory innovation as a kind of word game, which thinks of getting a few new concepts and new term as innovation; or thinks of making no sense to subvert the basic concept and the basic principle generally recognized by the academic circles as innovation; or even abandons the guidance of Marxism in the name of "innovation", ignores the essential attribute of ideological and political education are not theoretical innovation in the true sense. Such achievements, of course, have inferior quality.

The assessment of the quality of theoretical research achievements of ideological and political education discipline can not only rely on one or several dimensions, but needs the integrated use of position dimensions, practical dimensions, specification dimension and innovation dimension. Only takes care of all the dimensions can make a objective, fair and scientific evaluation to the quality of theoretical research achievements of ideological and political education discipline, and thus promote the sustainable development of the construction of ideological and political education, give full play of the effect of political education and serving the society.

\section{Acknowledgements}

Fund project This paper is phased achievement of the Chongqing social sciences planning project "Study of contemporary college students' approval of socialism with Chinese characteristics" (project approval NO: 2013 PYML04) and is funded by the Chongqing normal university fund project (project approval NO: 14XYY046

\section{References}

[1]Yu Yuhua. Improving theoretical consciousness of the construction of the ideological and political education discipline.[J]. Journal of ideological and theoretical education Tribune, 2013 :(8).

[2] Lenin Corpora (volume 39) [M], Beijing: People's Publishing House, 1986:298-299.

[3]Lenin Anthology (volume 1) [M], Beijing: People's Publishing House, 1995:326-327. 
[4] [5] [6] [7] [8] [9] Marx and Engels Anthology (volume 1) [M], Beijing: People's Publishing House, 2012:178, 137 138, 11, 153, $145 \sim 146,145$.

[10] Shen Zhuanghai, The academic standard of ideological and political education research[J]. Journal of ideological and theoretical education Tribune, 2012: (10).

[11] Han Hua. PhD thesis in recent 10 years of ideological and political education subject: review and reflection[J]. Journal of teaching and research, 2012: (12).

[12] Shen Zhuanghai, The independent character of ideological and political education research [J]. Journal of national institute of education administration, 2005: (2).

Author Jingkun Lu,mainly engaged in the theory and practice of Ideological and political education, is the associate professor in the School of Political Science in Chongqing Normal University. 